\title{
PERSEPSI TERHADAP KETERLIBATAN AYAH DALAM PENGASUHAN DAN KONSEP DIRI DENGAN KEMATANGAN EMOSI SISWI SMAN X TANGERANG
}

\section{Perception of Father's Involement in Parenting and Self Concept with Emotional Maturity of Female Students in Senior High School at Tangerang}

\author{
Arisia Tirtal), Selviana $^{2)}$ \\ 1), 2)Fakultas Psikologi, Universitas Persada Indonesia Y.A.I
}

Diterima tanggal 3 September 2019/ Disetujui tanggal 12 Oktober 2019

\begin{abstract}
This study aims to determine perception of father's involvement in parenting and self concept with the emotional maturity of female students at SMAN X Tangerang. The research approach in this study is quantitative type of multiple correlation. Respondents in this study consisted of 103 people with cluster sampling. Data were collected using the scale of emotional maturity, scale of perception of father's involement in parenting and scale of self concept; all were particularly developed by the researchers. The results revealed that there are partial and simultan correlation of father's involvement in parenting and self-concept toward on emotional maturity of young women. This shows the importance of father's involvement in parenting and positive self-concept to build an emotional maturity of young women.
\end{abstract}

Keywords: perception of father's involvement in parenting; self-concept; emotional maturity

\begin{abstract}
ABSTRAK
Penelitian ini bertujuan untuk mengetahui persepsi terhadap keterlibatan Ayah dalam pengasuhan dan konsep diri dengan kematangan emosi siswi SMAN X Tangerang. Pendekatan penelitian yang digunakan adalah kuantitatif berjenis korelasi ganda. Responden penelitian berjumlah 103 orang, diperoleh dengan cluster sampling. Pengumpulan data dengan menggunakan skala kematangan emosi, skala persepsi terhadap keterlibatan ayah dalam pengasuhan dan skala konsep diri yang dikembangkan oleh peneliti. Hasil penelitian menujukkan bahwa terdapat hubungan persepsi terhadap keterlibatan ayah dalam pengasuhan dan konsep diri dengan kematangan emosi siswi baik secara parsial maupun simultan. Hal ini menunjukan pentingnya keterlibatan ayah dalam pengasuhan dan konsep diri yang positif untuk membentuk kematangan emosi yang baik pada siswi.
\end{abstract}

Kata kunci: persepsi terhadap keterlibatan ayah dalam pengasuhan; konsep diri; kematangan emosi

\section{PENDAHULUAN}

Masa remaja didefinisikan sebagai periode transisi perkembangan dari masa kanakkanak hingga masa dewasa, yang melibatkan perubahan-pe rubahan biologis, kognitif, dan sosio-emosional (Santrock, 2007).

*Korespondensi

Penulis:

arisiatirta95@gmail.com 1 ,

selviana.psikologi@gmail.com²
Perubahan-perubahan yang terjadi pada masa remaja ini masih menjadi perhatian orang tua dalam mendidik anaknya. Pentingnya keterlibatan orang tua dalam pengasuhan remaja tidak terlepas dari keterlibatan ayah yang mulai mendapat perhatian dalam kaitannya dengan berbagai aspek kehidupan anak. Sesungguhnya peran dari ibu dan ayah saling melengkapi guna membentuk kematangan emosi seorang anak terutama pada masa remaja. Yusuf (2011) mengungkapkan kematangan emosi merupakan kemampuan individu untuk 
Versi Online: http://journal.ubm.ac.id/index.php/psibernetika DOI: http://dx.doi.org/10.30813/psibernetika.v12i2.1671 Hasil Penelitian

dapat bersikap toleran, merasa nyaman, perasaan mau menerima dirinya dan orang lain, serta mampu menyatakan dirinya secara konstruktif dan positif. Dalam hal ini, kondisi keluarga yang baik merupakan hal yang dapat membentuk diri anak yang positif di kemudian hari, yaitu apabila terdapat pengertian antara orang tua dan anak, terdapat keserasian antara ayah dan ibu dalam mengasuh anak, serta sikap mampu menerima yang ditunjukkan oleh orang tua terhadap anak, sehingga orang tua tidak akan terlalu menuntut anak. Terkait dengan kematangan emosi, terdapat beberapa faktor yang mempengaruhi perkembangan kematangan emosi menurut Ali dan Asrori (2015), antara lain: Perubahan jasmani, Perubahan pola interaksi ayah, Perubahan interaksi dengan teman sebaya, Perubahan pandangan luar dan Pendidikan. Lebih lanjut, kematangan emosi seseorang dipengaruhi oleh beberapa faktor, baik internal (dari dalam diri sendiri) maupun faktor eksternal (dari luar diri sendiri), yaitu antara lain adalah adanya konsep diri yang baik dan uasana lingkungan sosial.

Secara khusus, penelitian ini mengedepankan faktor keterlibatan ayah dalam pengasuhan remaja putri dan konsep diri yang diduga dapat memengaruhi kematangan emosi pada remaja putri. Berdasarkan wawancara yang dilakukan oleh penulis dengan guru Bimbingan dan Konseling di SMAN X Tangerang didapati bahwa terdapat beberapa masalah kematangan emosi remaja putri yang kurang terkontrol akibat kurangnya keterlibatan ayah dalam pengasuhan, antara lain kekerasan yang dilakukan oleh ayahnya, kurangnya perhatian karena ayah yang sibuk bekerja, hingga ayah yang sudah meninggal. Hal ini mengakibatkan rentannya kematangan emosi remaja putri di sekolah seperti menjadi anti terhadap teman laki-laki hingga mempengaruhi emosi pribadi yang membuatnya menjadi menjaga jarak dengan teman-temannya.

Sebagaimana diketahui, sebelum mengalami perasaan cinta terhadap lawan jenis, sosok ayah adalah cinta pertama bagi putrinya. Pyun (2014) menyatakan bahwa peran ayah sama besarnya dengan peran ibu
Jurnal Psibernetika Vol.12 (2): 52 - 57. Oktober 2019 p-ISSN: 1979-3707 e-ISSN: 2581-0871

untuk kesehatan mental anak. Semakin besar perhatian ayah dalam pengasuhan pada anak, semakin mungkin ayah mengetahui lebih banyak tentang temanteman anak, maka semakin besar pula dampaknya terhadap kehidupan anaknya ketika remaja dan berhadapan dengan pilihan yang berisiko. Meski sang ibu memiliki kemampuan untuk melakukan hal yang sama, namun ketika sang ayah yang memberi nasihat akan berdampak dua kali lipat. Pengalamannya dengan sosok ayah ini dapat menjadi bekal bagi remaja putri baik dalam bergaul dengan lawan jenis maupun dalam kematangan emosinya saat diperhadapkan pada pilihan-pilihan beresiko dikemudian hari. Hal ini diperkuat oleh penelitian Nabila dan Andayani (2019) yang menunjukkan bahwa adanya hubungan signifikan antara keterlibatan pengasuhan orang tua laki-laki dengan efikasi menjadi seorang ayah empatik. Dengan kata lain, keterlibatan pengasuhan ayah merupakan hal yang penting karena akan menjadi model dirinya berperilaku kepada anaknya, sehingga anak memiliki kematangan emosi yang baik dalam membawa diri kepada lingkungan sosialnya.

Faktor lainnya adalah konsep diri yang penting bagi individu karena terbentuk dari masa kanak-kanak. Ketika menginjak remaja, individu yang memiliki konsep diri positif akan mampu menerima kritik dan saran dari orang lain mengenai keburukan atau kekurangan yang dimiliki, sehingga akan selalu mengingat hal-hal positif yang dialaminya seperti julukan yang melekat pada dirinya yang berdasarkan atas kelebihan yang dimiliki dan akan merasa jika bisa menjadi individu yang diterima dalam keluarganya saat ini dan adanya penerimaan terhadap diri remaja. Dengan begitu, konsep diri yang positif dapat membuat remaja putri menjadi lebih matang secara emosi. Hal ini sesuai dengan penelitian Mayaza dan Supradewi (2011) bahwa individu yang memiliki konsep diri yang positif akan dapat mengenal dirinya dengan baik, sehingga dapat mengenali segala kelemahan dan kelebihan yang dimilikinya serta membuat individu dapat menentukan arah hidup serta cara yang 
Versi Online: http://journal.ubm.ac.id/index.php/psibernetika DOI: http://dx.doi.org/10.30813/psibernetika.v12i2.1671 Hasil Penelitian

tepat untuk mengatasi dan menyalurkan emosinya.

Berdasarkan uraian di atas, maka penelitian ini bertujuan untuk mengetahui hubungan keterlibatan ayah dalam pengasuhan dan konsep diri dengan kemantangan emosi pada remaja putri yang dapat dihipotesiskan bahwa 1). Ada hubungan keterlibatan ayah dala pengasuhan dengan kematangan emosi pada remaja putri; 2). Ada hubungan konsep diri dengan kematangan emosi pada remaja putri; 3). Ada hubungan keterlibaan ayah dalam pengasuhan dan konsep diri dengan kematangan emosi pada remaja putri.

\section{Kematangan Emosi}

Kematangan emosi merupakan kemampuan individu untuk dapat menggunakan emosinya dengan baik serta dapat menyalurkan emosinya pada hal-hal yang bermanfaat, tetapi bukan menghilangkan emosi yang ada pada dirinya (Davidoff dalam Asih \& Pratiwi, 2010). Dengan kata lain, setiap orang pasti memiliki emosi yang dalam suatu kondisi tertentu dapat terluapkan, tetapi individu yang matang secara emosi adalah individu yang mampu mengekspresikan emosinya pada hal yang positif, bermanfaat dan tidak merugikan diri sendiri serta orang lain.

Pendapat lain dikemukakan oleh Sartre (2002) yang mengatakan bahwa kematangan emosi adalah keadaan seseorang yang tidak cepat terganggu rangsang yang bersifat emosional, baik dari dalam maupun dari luar dirinya, selain itu individu yang matang secara emosi dapat bertindak dengan tepat dan wajar sesuai dengan situasi dan kondisi.

Berdasarkan uraian di atas, dalam penelitian ini kematangan emosi merupakan suatu keadaan individu yang mampu mengendalikan dirinya dan mengekspresikannya secara tepat dan wajar sesuai situasi dan kondisi.

\section{Persepsi Terhadap Keterlibatan Ayah dalam Pengasuhan}

Lamb (2010) menjelaskan bahwa keterlibatan ayah dalam pengasuhan merupakan keikutsertaan positif ayah dalam kegiatan yang berupa interaksi langsung
Jurnal Psibernetika

Vol.12 (2): 52 - 57. Oktober 2019

p-ISSN: 1979-3707

e-ISSN: 2581-0871

dengan anak-anaknya, memberikan kehangatan, melakukan pemantauan dan kontrol terhadap aktivitas anak, serta bertanggung jawab terhadap keperluan dan kebutuhan anak. Dalam hal ini, Ayah memiliki peran yang khas pada setiap tahapan perkembangan anak. Pruett (dalam Lentari et al, 2017) mengungkapkan bahwa pada remaja ayah berperan dalam membangun harga diri yang tetap positif dan juga menguatkan keinginan anak untuk berprestasi khususnya pada remaja putri, serta mengembangkan motivasi untuk sukses dalam pekerjaan dan motivasi untuk melanjutkan pendidikan ke jenjang yang lebih tinggi pada remaja laki-laki.

Terkait peran ayah dalam keterlibatannya dalam pengasuhan, Hart (dalam Dagun, 1990) menyatakan bahwa ayah memiliki peran dalam keterlibatannya dalam keluarga yaitu: 1). Economic Provider, ayah dianggap sebagai pendukung finansial; 2). Friend \& playmate, ayah dianggap sebagai fun parent (orang tua yang menyenangkan); 3). Caregiver, ayah memberikan rasa nyaman dan penuh kehangatan; 4). Teacher \& role model, ayah bertanggung jawab terhadap apa aja dibutuhkan anak untuk masa depannya; 5). Monitor and disciplinary, ayah memenuhi peranan penting dalam pengawasan terhadap anak; 6).Protector, ayah mengontrol dan mengorganisasi lingkungan anak; 7). Advocate, ayah menjamin kesejahteraan anaknya; 8). Resource, ayah mendukung keberhasilan anak memberikan dukungan di belakang layar.

Berdasarkan uraian di atas, dalam penelitian ini keterlibatan ayah dalam pengasuhan yaitu persepsi anak terhadap keikutsertaan ayah dalam interaksi langsung dengan anak perempuannya seperti menjadi teman bermain, teman cerita, teman mejelajah dan mencoba hal-hal baru serta bertanggung jawab terhadap kebutuhan anak.

\section{Konsep Diri}

Konsep diri adalah penilaian remaja tentang diri sendiri yang bersifat fisik, psikis, sosial, emosional, aspirasi, dan prestasi. Konsep diri fisik adalah gambaran 
Versi Online: http://journal.ubm.ac.id/index.php/psibernetika DOI: http://dx.doi.org/10.30813/psibernetika.v12i2.1671 Hasil Penelitian

remaja tentang arti penting tubuhnya dalam hubungannya dengan perilakunya. Konsep diri psikis adalah gambaran remaja tentang harga dirinya dan hubungannya dengan orang lain. Konsep diri sosial adalah gambaran remaja tentang hubungannya dengan orang lain. Konsep diri emosional adalah gambaran remaja tentang emosi diri, seperti kemampuan menahan emosi, pemarah, sedih, atau riang-gembira dan ainlain. Konsep diri aspirasi adalah gambaran remaja tentang pendapat dan gagasan, kreativitas, dan cita-cita. Konsep diri prestasi adalah gambaran remaja tentang kemajuan dan keberhasilan yang akan diraih (Hurlock, 2012).

Pendapat lain tentang konsep diri menurut Rahmaningsih dan Martini (2014) adalah gambaran individu tentang diri sendiri di masa sekarang, pengharapan tentang diri sendiri di masa depan, serta penilaian individu terhadap diri sendiri yang menentukan tingkat harga diri. Hal ini mengacu pada penilaian-penilaian atas diri sendiri yang diperoleh berdasarkan pengetahuannya atas diri sendiri.

Berdasarkan uraian di atas, dalam penelitian ini konsep diri adalah penilaian dan gambaran remaja putri berdasarkan pengetahuannya atas segala sesuatu tentang diri sendiri.

\section{METODE PENELITIAN}

Pada penelitian ini, pendekatan penelitian yang digunakan yaitu penelitian kuantitatif jenis korelasional.

\section{Responden Penelitian}

Responden dalam penelitian ini adalah remaja putri usia 15-16 tahun kelas XI SMAN X berjumlah 143 orang yang berdasarkan tabel Morgan, sampel yang digunakan dari suatu populasi yang berjumlah 143 orang adalah 103 orang. Responden yang dilibatkan dalam penelitian ini adalah siswi yang berada di kelas XI IPA 1, XI IPA 2, X1 IPS 1 dan XI IPS 2.

Siswi berusia 15-16 tahun mulai memasuki masa remaja yang biasanya menyukai hal-hal baru untuk dilakukan, sehingga pembentukan konsep diri dan
Jurnal Psibernetika

Vol.12 (2): 52 - 57. Oktober 2019

p-ISSN: 1979-3707

e-ISSN: 2581-0871

peran orang tua termasuk ayah dibutuhkan dalam membentuk kematangan emosinya.

\section{Instrumen Penelitian}

Pada penelitian ini digunakan skala kematangan emosi diukur berdasarkan aspek-aspek yang dikemukakan oleh Walgito (2003) meliputi: dapat menerima diri sendiri dan orang lain apa adanya, mampu mengontrol dan mengarahkan emosi, mampu menyikapi masalah secara positif, tidak mudah frustasi terhadap permasalahan yang muncul, mempunyai tanggung jawab, kemandirian, dan kemampuan beradaptasi. Terdiri dari 24 aitem yang disusun sendiri oleh peneliti dengan model Likert. Contoh aitem: "Saya dapat menahan diri menghadapi orang yang menjengkelkan". Skor cronbach alpha sebesar .682 dari 24 aitem, ada 20 aitem valid dan 4 aitem gugur.

Berikutnya skala persepsi terhadap keterlibatan ayah diukur berdasarkan aspekaspek yang dikemukakan oleh Lamb et al (dalam Allgood, Troy \& Camille, 2012) meliputi: paternal engagement, paternal accessibility, dan paternal responsibility. Terdiri dari 18 aitem yang disusun sendiri oleh peneliti dengan model semantic differential. Contoh aitem: "Persepsi terhadap Ayah (Mendengarkan /Mengabaikan)". Skor cronbach alpha sebesar .692 dari 18 aitem, ada 13 aitem valid dan 5 aitem gugur.

Selanjutnya skala konsep diri diukur berdasarkan aspek-aspek yang dikemukakan oleh Calhoun dan Acocella (dalam Ghufron \& Risnawita, 2014) meliputi: pengetahuan, harapan, dan penilaian. Terdiri dari 18 aitem yang disusun sendiri oleh peneliti dengan model Likert. Contoh aitem: "Saya adalah orang yang baik". Skor cronbach alpha sebesar .624 dari 18 aitem, ada 14 aitem valid dan 4 aitem gugur.

\section{Teknik Analisis Data}

Teknik analisis data yang digunakan dalam penelitian ini adalah analisis kuantitatif yang menggunakan 
Versi Online: http://journal.ubm.ac.id/index.php/psibernetika DOI: http://dx.doi.org/10.30813/psibernetika.v12i2.1671 Hasil Penelitian

program SPSS dengan menggunakan uji korelasi ganda.

\section{HASIL DAN PEMBAHASAN}

Analisis data diuji dengan korelasi ganda. Lebih lengkap, hasil analisis data tersaji pada tabel berikut:

Tabel 1. Hasil Uji Korelasi

\begin{tabular}{lccc}
\hline \multirow{2}{*}{ Variabel } & \multicolumn{3}{c}{ Kematangan Emosi } \\
\cline { 2 - 4 } & $\mathrm{R}$ & Rsquare & $\mathrm{p}$ \\
\hline Keterlibatan & .274 & .075 & .001 \\
Ayah & & & \\
Konsep diri & .261 & .052 & .003 \\
Keterlibatan & .277 & .077 & .000 \\
Ayah \& & & & \\
Konsep diri & & & \\
\hline
\end{tabular}

Berdasarkan hasil analisis yang dilakukan terhadap 103 remaja putri di SMAN X Tangerang dapat disimpulkan bahwa terdapat hubungan antara persepsi terhadap keterlibatan Ayah dalam Pengasuhan dengan kematangan emosi remaja putri di SMAN X Tangerang dengan $\mathrm{r}=.274 ; \mathrm{p}<.05$ dan kontribusi (Rsquare) $=$ .075 atau $7.5 \%$, Hipotesis diterima. Hal ini berarti bahwa semakin besar perhatian ayah dalam pengasuhan pada putrinya, maka semakin besar pula dampaknya terhadap kehidupan remaja putri ketika berhadapan dengan pilihan yang berisiko. Hasil ini sejalan dengan penetlian Rizkyta dan Fardana (2017) bahwa terdapat korelasi positif persepsi keterlibatan ayah dalam pengasuhan dengan kematangan emosi pada remaja.

Hasil analisis penelitian berikutnya dapat disimpulkan bahwa terdapat hubungan antara konsep diri dengan kematangan emosi remaja putri di SMAN $\mathrm{X}$ Tangerang dengan $\mathrm{r}=.261 ; \mathrm{p}<.05$ dengan kontribusi (Rsquare) $=.052$ atau $5.2 \%$, hipotesis diterima. Hal ini menunjukkan semakin baik konsep diri yang dimiliki remaja putri atas dirinya sendiri, maka kematangan emosi yang dimiliki pun baik. Hasil tersebut sejalan dengan pandangan Shavelson \& Roger (dalam Muawanah et al, 2012) bahwa pengembangan konsep diri berpengaruh
Jurnal Psibernetika

Vol.12 (2): 52 - 57. Oktober 2019

p-ISSN: 1979-3707

e-ISSN: 2581-0871

terhadap perilaku yang ditampilkan, sehingga bagaimana orang lain memperlakukan dan apa yang dikatakan orang lain tentang individu akan dijadikan acuan untuk menilai diri sendiri yang pada akhirnya mengarah kepada kematangan emosinya.

Lebih lanjut, hasil analisis penelitian ini menyimpulkan bahwa terdapat hubungan antara persepsi terhadap keterlibatan Ayah dalam pengasuhan dan konsep diri dengan kematangan emosi remaja putri di SMAN X Tangerang dengan $\mathrm{r}=.277 ; \mathrm{p}<0,05$ dengan kontribusi (Rsquare) $=.077$ atau $7.7 \%$, hipotesis diterima. Hal ini menunjukan bahwa semakin terlibatnya ayah dalam pengasuhan dan konsep diri yang baik pada remaja putri maka akan diikuti dengan kematangan emosi yang baik pula. Faktor-faktor lain yang memiliki kontribusi lebih besar dalam mempengaruhi kematangan emosi menurut Ali dan Asrori (2015), antara lain Perubahan jasmani, Perubahan interaksi dengan teman sebaya, perubahan pandangan luar, pendidikan, adanya penyesuaian diri yang baik dan suasana lingkungan sosial.

\section{SIMPULAN}

Berdasarkan hasil penelitan, maka dapat ditarik kesimpulan bahwa: 1). Terdapat hubungan yang positif antara keterlibatan ayah dalam pengasuhan dengan kematangan emosi remaja putri SMAN X Tangerang; 2). Terdapat hubungan yang positif antara konsep diri dengan kematangan emosi remaja putri SMAN X di Tangerang; 3). Terdapat hubungan yang positif antara keterlibatan ayah dalam pengasuhan dan konsep diri dengan kematangan emosi remaja putri SMAN X di Tangerang.

Secara teoritis, disarankan bagi penelitian selanjutnya dapat menggunakan variabel pola asuh, lingkungan belajar atau kontrol diri yang diduga dapat berhubungan dengan kematangan emosi remaja.

Secara praktis, disarankan agar ayah bisa lebih dekat dengan remaja putrinya sehingga mampu memantau perkembangan putrinya terutama dalam 
Versi Online: http://journal.ubm.ac.id/index.php/psibernetika DOI: http://dx.doi.org/10.30813/psibernetika.v12i2.1671 Hasil Penelitian

kematangan emosinya, mengingat cinta pertama bagi seorang anak perempuan adalah ayahnya. Bagi remaja putri juga disarankan agar dapat lebih terbuka pada ayahnya, tidak sungkan untuk meminta bantuan bahkan menceritakan tentang kehidupannya agar mendapatkan perhatian dan arahan dari ayahnya.

\section{DAFTAR PUSTAKA}

Ali, M., \& Asrori, M. (2006). Psikologi remaja: Perkembangan peserta didik. Jakarta: Bumi Aksara.

Allgood, S. M., Beckert, T. E., \& Peterson, C. (2012). The role father involvement in the percieved psychological well being of young adutl daughter. North American Journal of Psychology, 14(1), 95110.

Asih, G. Y., \& Pratiwi, M., M., S. (2010). Perilaku Prososial ditinjau dari Empati dan Kematangan Emosi. Jurnal Psikologi Universitas Muria Kudus. 1 (1), 33-42. Diperoleh pada 29 Juni 2018 dari: http://jurnal.umk.ac.id/index.php/P SI/article/viewFile/23/22

Dagun, S. M. (1990). Psikologi keluarga: Peranan Ayah dalam keluarga. Jakarta: Rineka Cipta.

Ghufron , M. N., \& Risnawita, R. (2014). Teori-teori psikologi. Yogyakarta: Ar-Ruzz Media.

Hadi, S. (2004). Metodologi riset. Yogyakarta: Pustaka Pelajar.

Hurlock, E. B. (2004). Psikologi Perkembangan: Suatu pendekatan sepanjang rentang kehidupan. Edisi ke V. Jakarta: Erlangga.

Lamb, M. E. (2010). The role of father in child development. New York: John Wiley and Son.

Mayaza, K., \& Supradewi, R. (2011). Konsep diri dan kebermaknaan hidup pada remaja di Panti Asuhan. Proyeksi, 6(2), 103-112.

Muawanah, L., Pratikto, H., \& Suroso. (2012). kematangan emosi, konsep
Vol.12 (2): 52 - 57. Oktober 2019

p-ISSN: 1979-3707

e-ISSN: 2581-0871

diri dan kenakalan remaja. Jurnal Persona, 1(01), 8.

Nabila, H. R., \& Andayani, B. (2019). Hubungan antara keterlibatan pengasuhan orang tua laki-laki dengan efikasi menjadi Ayah yang empatik. Gajah Mada Journal of Psychology, 5(1), 1-6.

Pyun, Y. S. (2014). The influence of fatherchild relationship on adolescents' mental health (Unpublished theses). Minnesota State University, Mankato.

Rahmaningsih, N. D., \& Martani, W. (2014). Dinamika konsep diri pada remaja perempuan pembaca teenlit. Jurnal Psikologi, 41(2), 179-189.

Rizkyta. D. P., \& Fardana, N. A. (2017). Hubungan antara persepsi keterlibatan ayah dalam pengasuhan dan kematangan emosi pada remaja. Jurnal Psikologi Pendidikan dan Perkembangan, 6, 1-13.

Santrock, J. W. (2007). Remaja - Jilid 1 (11 ed.). Jakarta: Erlangga.

Sartre, J. P. (2002). Pengantar teori emosi. Yogyakarta: Pustaka Pelajar.

Sugiyono. (2009). Metode Penelitian Kuantitatif kualitatif dan $R \& D$. Bandung: Alfabeta.

Walgito. (2003). Psikologi sosial (Suatu Pengantar).Yogyakarta: Andi Ofset.

Yusuf, S. (2011). Psikologi perkembangan anak \& remaja. Bandung: PT Remaja Rosdakarya. 